\title{
Construction and Characterization of Novel Chimeric $\beta$-Glucosidases with Cellvibrio gilvus (CG) and Thermotoga maritima (TM) by Overlapping PCR
}

\author{
Kim Jong Deogi and Hayashi Kiyoshi ${ }^{2}$ \\ ${ }^{1}$ Department of Biotechnology, Research Center on Anti-Obesity and \\ Health Care (RCAOHC), Chonnam National University, Yosu \\ ${ }^{2}$ National Food Research Institute, Tskuba \\ ${ }^{1}$ Korea \\ ${ }^{2}$ Japan
}

\section{Introduction}

It is known that $\beta$-glucosidase is very important for obtaining clean energy from cellulolytic materials such as plants and wood. For most bioconversion processes with cellulose, endo(1$4)$ - $\beta$-D-glucan glucanhydrolases and exo(1-4)- $\beta$-D-glucan cellobiohydrolases are necessary for catalyzing the random hydrolysis of cellulose to produce cellobiose. On the basis of substrate specificity, $\beta$-glucosidases can be classified into aryl- $\beta$-glucosidases, cellobioses hydrolysing only oligosaccharides, and those hydrolysing both aryl- $\beta$-glucosides and oligosaccharides $[1,2]$. $\beta$-glucosidases are important components of the cellulase enzyme complex required for the hydrolysis of cellulose into glucose by catalysing the final step, which is the conversion of cellobiose into glucose [3]. From the basis of sequence homology $\beta$-glucosidases have been divided into two sub-families, namely BGA ( $\beta$-gucosidases and phospho- $\beta$-glucosidases from bacteria to mammals) and BGB ( $\beta$-glucosidases from yeast, mold and rumen bacteria) [4]. The study of these enzymes has been facilitated by the use of recombinant DNA technology $[5,6,7,8]$. A number of cellulase genes including several forms of $\beta$-glucosidases, have been cloned and expressed in both E.coli and S.cereviciae $[9,10]$. In recent years, protein engineering has become an increasingly important tool in the development of novel hybrid enzymes with useful catalytic functions [11,12,13]. The catalytic activities and thermal stabilities of enzymes can be improved by the construction of chimeric enzymes with gene-shuffling from different species of genes [14]. For this purpose, chimeric genes are normally constructed by the application of one of two methods: using restriction enzymes or by overlapping polymerase chain reaction (PCR) [15]. Although the use of restriction enzymes is the easier method, a high level of identity is required between the parental DNA sequences to obtain common restriction enzyme sites in both genes. Often, the availability of common restriction enzyme sites limits the use of this strategy in the construction of chimeric genes. In contrast, there are no such limitations in defining shuffling sites for chimeric genes constructed via overlapping PCR technique. 
In order to construct new types of the chimeric $\beta$-glucosidases, Thermotoga maritima (TM) gene and Celvibrio gilvus (CG) gene were used for gene-shuffling. Celvibrio gilvus [16], a cellulose-metabolizing bacterium, has the unique property of producing cellobiose in high yields from acidic swollen cellulose. Thermotoga maritima is a fermentative, marine, hyperthermophilic eubacterium that can be grown in temperatures of up to $90^{\circ} \mathrm{C}$ with an optimal temperature of around $80^{\circ} \mathrm{C}[17,18]$. Two novel active $\beta$-glucosidase were successfully constructed from the pool of chimeric genes and their properties were characterized. These results proved the chimeric gene construction is promising approach for searching for the better $\beta$-glucosidase

\section{Materials and methods}

\section{Bacterial strain and plasmids}

The plasmids pET-CG and pET-TM were constructed by introducing the CG gene and the TM gene for $\beta$-glucosidase into the pET28a (+) vector (Novagen, Germany) carrying an Nterminal His tag and a thrombin cleavage site. Topo-XL TOP 10 (Invitrogen, USA) was used for cloning of chimeric genes, and the pET28 (a) vector was used for introducing the TopoXL-chimeric gene. The BL21 (DE3) (NextGen Sciences, Inc., USA) strain was used for expression of the chimeric protein produced through the pET28a $(+)$ vector.

\section{Overlapping PCR for chimeric gene}

For the construction of 8 kinds of chimeric genes from CG and TM, three steps of PCR were applied. The first step was the amplification of gene fragments for domain-shuffling using the CG and TM gene as templates for overlapping PCR. The outside primer was prepared from the shuffling region of both templates and contained the restriction site, while the inside primer contained the opposite gene region. The second step involved targeting the chimeric gene with overlapped PCR from the templates prepared in the first step. At this stage the primers were not used as this step was exclusively focused on annealing of the two templates of CG and AT genes. PCR was initially performed at $98^{\circ} \mathrm{C}$ for $3 \mathrm{~min}$, in order to convert the single DNA into a template. Polymerase was not added in this step. PCR was repeated at $25^{\circ} \mathrm{C}$ for $1 \mathrm{hr}$ for purposes of overlapping both genes. DNA polymerase was then added and $15 \mathrm{PCR}$ cycles were performed at $25^{\circ} \mathrm{C}$. This completed the construction of the chimeric gene. The third step involved the amplification of the newly constructed chimeric gene using the primers from the first step, allowing for an exponential increase in the amount of chimeric genes produced.

\section{Primers}

Each chimeric gene required 4 primers to be constructed, and thus, 20 kinds of primers (forward and reverse) were designed as Figure 1 and Table 1. Figure 1 showed the position of forward and reverse primers and Table 1 explained the structure of primers for each chimeric gene, respectively.

\section{Cloning and colony PCR}

All PCR products were purified after agarose gel electrophoresis, using the QIAquick PCR purification kit (QIAGEN, Germany). The amplified chimeric genes were cloned using the pCR-TOPO cloning kit (Invitrogen, USA). The resulting recombinant pCR-TOPO plasmid 


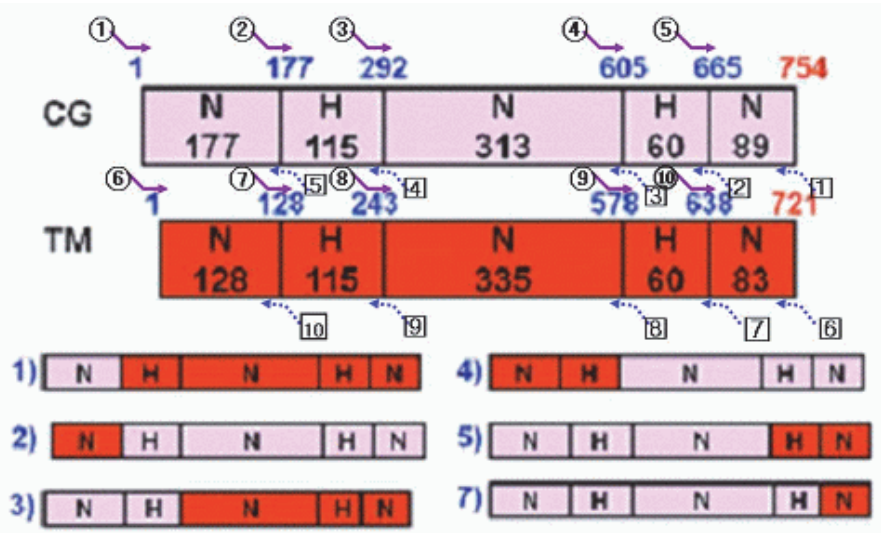

6)

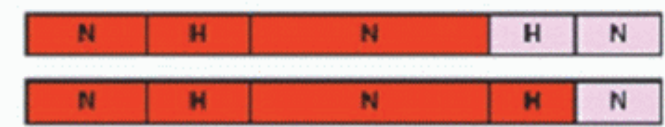

Fig. 1. Design of 8 kinds of chimeric $\beta$-glucosidase gene from CG and TM with higher homology region. Numerics in bold gothic are designated as numbers of amino acids, and numerics in circle are designated as forward primers, in square are reverse primers for constructing chimeric enzymes. N: non-homology region, H: higher homology region.

containing chimeric $\beta$-glucosidase genes was confirmed by colony PCR, and then extracted using a QIAminiprep kit (QIAGEN, Germany), and sequenced with a DNA sequencer (Model 373A, Applied Biosystem, USA). The sequence data was analyzed using the GENETYX program (Software Development Co., Tokyo, Japan).

\section{Selection of active clonies}

The TOPO-cloned chimeric $\beta$-glucosidase genes were transferred into the pET28a (+) vector with hydrolysing NdeI and HindIII restriction enzymes. The host E.coli BL21 (DE3) competent cells were tranformed with pET28a (+) vector carrying the chimeric $\beta$ glucosidase genes to check its activity. Active colonies were selected with solid medium including pNP-glucopyranoside.

\section{Purification of enzymes}

BL21 (DE3) cells carrying the chimeric gene were cultivated in Luria-Bertani broth (LB) medium $(1000 \mathrm{ml})$ containing kanamycin $(30 \mathrm{mg} / \mathrm{ml})$ at $37^{\circ} \mathrm{C}$. On reaching an optimum density of 0.2 at $600 \mathrm{~nm}$, protein production was induced by the addition of $1 \mathrm{mM}$ isopropyl- $\beta$-D-thiogalactopyranoside (IPTG) into the culture media and incubating it overnight. When the absorbance of the broth at $660 \mathrm{~nm}$ reached values between $0.4-0.5$, the cells were harvested by centrifugation $\left(8,000 \mathrm{rpm}, 10 \mathrm{~min}\right.$ at $\left.4^{\circ} \mathrm{C}\right)$ and suspended in $50 \mathrm{mM}$ MOPS buffer $\mathrm{pH}$ 6.5. The cells were then disrupted by sonication (Branson sonifier 250D). The intact cells and debris were removed by centrifugation $\left(12,000 \mathrm{rpm}, 10 \mathrm{~min}\right.$ at $\left.4^{\circ} \mathrm{C}\right)$.

Purification was achieved by binding of the cleared lysate with Ni-NTA resin, which bound to the target protein. This resin was then packed into a column to facilitate the washing and 


\begin{tabular}{|c|c|c|c|c|}
\hline \multirow{2}{*}{$\begin{array}{c}\text { Chimera } \\
\text { No }\end{array}$} & \multicolumn{2}{|c|}{ 1st PCR primer } & \multicolumn{2}{|c|}{ Overlapping PCR primer } \\
\hline & FWD & REV & FWD & REV \\
\hline & (1) & 5 & (2) & 6 \\
\hline 1) & $\begin{array}{c}\text { ccatgggcagcagc } \\
\text { catc }\end{array}$ & $\begin{array}{l}\text { ttccttcegttgcgc } \\
\text { ggctcg }\end{array}$ & $\begin{array}{c}\text { gccgcgcaacggaag } \\
\text { gaatttcgagtacta }\end{array}$ & $\begin{array}{l}\text { aagcttatggttt } \\
\text { gaatctcttct }\end{array}$ \\
\hline & (6) & 10 & (7) & 1 \\
\hline 2) & $\begin{array}{c}\text { ccatatggaaaggat } \\
\text { cgatg }\end{array}$ & $\begin{array}{c}\text { agttgcggccacaa } \\
\text { agagggtttctgtgaat }\end{array}$ & $\begin{array}{c}\text { ccctctttgtggccgcaa } \\
\text { cttcgaatac }\end{array}$ & $\begin{array}{c}\text { caagctttcagcgtg } \\
\operatorname{cgc}\end{array}$ \\
\hline 3) & (1) & $\begin{array}{c}4 \\
\text { ctcccgegtaccagt } \\
\text { cggacatgacataac } \\
9\end{array}$ & $\begin{array}{c}3 \\
\text { gtccgactggtacg } \\
\text { cgggagacaac } \\
\text { 8 }\end{array}$ & 6 \\
\hline 4) & (6) & $\begin{array}{l}\text { gggtggcgccccag } \\
\text { tcgctcatcacgaaa }\end{array}$ & $\begin{array}{c}\text { gagcgactggggcg } \\
\text { cсасcса }\end{array}$ & 1 \\
\hline 5) & (1) & $\begin{array}{c}8 \\
\operatorname{acctgtatccgaccgc} \\
\text { cgcacc }\end{array}$ & $\begin{array}{c}4 \\
\text { tgcggcggtcgcatacagg } \\
\text { tactacgacacc }\end{array}$ & 6 \\
\hline 6) & (6) & $\begin{array}{c}3 \\
\text { acttgtagcccacgtagatgtcttcct }\end{array}$ & $\begin{array}{c}9 \\
\text { cattcacgtgggctacaa } \\
\text { gtggttcgacct }\end{array}$ & 1 \\
\hline 7) & (1) & $\begin{array}{c}7 \\
\text { gagctttgatgtacac } \\
\text { ctgcggcacgtc } \\
2\end{array}$ & $\begin{array}{c}5 \\
\text { gcaggtgtacatcaa } \\
\text { agctccaaaa } \\
\text { (10) }\end{array}$ & 6 \\
\hline 8) & (6) & $\begin{array}{l}\text { tcggcgcggcgtaga } \\
\text { cctgtgagacttcctt }\end{array}$ & $\begin{array}{c}\text { acaggtctacgccgcg } \\
\text { ccga }\end{array}$ & 1 \\
\hline
\end{tabular}

Table 1. Forward and reverse primers for constructing each chimeric gene.

elution steps. Washing and elution were performed by the batch procedure described in TheQIA expressionist TM (QAIGEN, Germany) with a step gradient of $250 \mathrm{mM}$ imidazol in $50 \mathrm{mM}$ Na-phosphate buffer, $\mathrm{pH}$ 8.0. The fractions of $1 \mathrm{ml}$ were collected and assayed for chimeric $\beta$-glucosidase activity. The active fractions were combined and dialyzed against 5 $\mathrm{mM}$ MOPS buffer, $\mathrm{pH} 6.5$ overnight at $4^{\circ} \mathrm{C}$. The dialysed enzyme solution was futher purified on a Mono-S HR 5/5 column (Pharmacia, Sweden) equilibrated with $20 \mathrm{mM}$ acetate buffer ( $\mathrm{pH}$ 5.0). Chromatography was performed with a linear gradient of $\mathrm{NaCl}(20 \mathrm{ml}, 0-0.5$ M) at a flow rate of $1.0 \mathrm{ml} / \mathrm{min}$ using a Pharmacia FPLC system (Sweden). The removal of salt from the pooled active fraction was performed by dialyzing against $5 \mathrm{mM}$ MPOS buffer, $\mathrm{pH}$ 6.5.

\section{Enzyme assay}

The enzyme activity of chimeric $\beta$-glucosidase was determined by measuring the absorbance at $405 \mathrm{~nm}$, which was related to the amount of pNP (p-nitrophenol) released from the $\mathrm{pNP}-\beta$-D-glucopyranoside by the enzyme at $30^{\circ} \mathrm{C}$. The assay mixture, consisting of $5 \mathrm{mM}$ substrate (pNP- $\beta$-D-glc) and $50 \mathrm{mM}$ MOPS buffer ( $\mathrm{pH}$ 6.5) was incubated with the enzyme, in a total volume of $0.5 \mathrm{ml}$. The reaction was stopped by the addition of $0.5 \mathrm{ml}$ of 
$0.2 \mathrm{M}$ glycine- $\mathrm{NaOH}$ ( $\mathrm{pH}$ 10.5). One unit of $\beta$-glucosidase was defined as the amount of enzyme releasing 1 pmole of p-nitrophenol per minute under the above-mentioned conditions.

\section{SDS-page}

Sodium dodecyl sulfate polyacrylamide gel electrophoresis (SDS-PAGE) was conducted on $1 \mathrm{~mm}$ thick, $12 \%$ acrylamide slab gels. The samples were dissolved in Tris/ $\mathrm{HCl}$ loading buffer containing 1\% (w/v) SDS, 20\% (v/v) glycerol and 2\% (v/v) 2-mercaptoethanol and then heated at $95^{\circ} \mathrm{C}$ in heating block for $5 \mathrm{~min}$. Proteins were stained with $1 \%(\mathrm{w} / \mathrm{v})$ Coomassie Brilliant Blue R 250 in methanol/acetic acid/water (30:10:60), and then destained with the electric-range.

\section{Stability and optimization of $\mathrm{pH}$ and temperature}

To determine the effect of $\mathrm{pH}, 50 \mathrm{mM}$ concentrations of various buffers namely sodium phosphate ( $\mathrm{pH}$ 1.1-3.1), sodium formate ( $\mathrm{pH}$ 2.8-4.45), sodium succinate ( $\mathrm{pH} 3.23-6.4), 3-[\mathrm{N}-$ morpholino]propanesulfonic acid (MOPS; $\mathrm{pH}$ 6.2-8.18), N-[2-hydroxyethyl] piperazine-N'-[2ethanesulfinic acid] (HEPES; $\mathrm{pH}$ 5.93-9.13), piperidine ( $\mathrm{pH}$ 10.0-12.0), 2-[Ncyclohexylamino]ethanesulfonic acid (CHES; pH8.15-10.2), Mcllvaine buffer (pH 2.6-7.6) were used at $30^{\circ} \mathrm{C}$. A test of the $\mathrm{pH}$ stability of the enzyme at $30^{\circ} \mathrm{C}$ was performed by pre-incubating the enzyme with each of the above buffers for $30 \mathrm{~min}$ and determining the remaining activity using a standard procedure. For optimum $\mathrm{pH}$, the enzyme was incubated with substrates in each of the above buffers at $30^{\circ} \mathrm{C}$ for $10 \mathrm{~min}$, then reaction was stopped with $0.5 \mathrm{M}$ glycine $(\mathrm{pH}$ 10.3) solution, and followed enzyme assay. The optimum temperature of the enzyme was determined by incubating with substrates in a temperature range from $20^{\circ} \mathrm{C}$ to $100^{\circ} \mathrm{C}$ for 10 min, at three different $\mathrm{pH}$ levels, $\mathrm{pH} 3.0,4.5$ and 5.0, and analysed the enzyme activity. Similarly, the thermal stability of the enzyme was also determind by incubating the purified protein for $30 \mathrm{~min}$ at temperatures ranging from 20 to $100^{\circ} \mathrm{C}$. After cooling the sample on ice for $10 \mathrm{~min}$, the remaining activity was determined using standard procedures.

\section{Kinetic parameters}

Michaelis-Menten constants were determined from Line Weaver-Burk plots. The data used were obtained by measuring the initial rate of $\mathrm{pNP}$-glucose hydrolysis by incubating the enzyme with appropriate concentrations of the substrate in $25 \mathrm{mM}$ MOPS at $30^{\circ} \mathrm{C}$. The reaction was monitored at $405 \mathrm{~nm}$ on a Beckman spectrophotometer (model DU 640, USA) equipped with a temperature-controlled cell holder. The initial rate was determined at six different concentrations ranging from approximately 0.5 to 2.0 times the $\mathrm{Km}$. The catalytic constant Kcat was deduced using the molecular mass of $80 \mathrm{kDa}$, while the kinetic parameters (KM and Vmax) with their standard error was determined using the linear regression analysis.

\section{Results and discussion}

\section{Structure of chimeric $\beta$-glucosidases gene}

The characterization of $\beta$-glucosidase from CG and TM, as well as the cloning and analysis of the gene coding for these enzymes have previously been investigated by the National 
Food Research Institute (NFRI). Based on the amino acid alignment between TM and CG enzymes, an N-terminal domain, a C-terminal region, and a non-homologus region were reported $(5,16)$. The amino acid homology between TM and CG was $30.7 \%$. The homology of $\mathrm{N}$-terminal region and C-terminal region were found to be $32 \%$ and $36 \%$, respectively, both of which fall within the highly homologus regions of the amino acid sequence. From these data, 8 kinds of chimeric $\beta$-glucosidases were designed from the TM gene and CG gene as shown in Fig. 1, and these chimeras were constructed by overlapping PCR.

\section{Confirmation of introduced chimeric genes}

After conducting overlapping PCR for construction of 8 chimeric genes, the PCR products were introduced into the pCR-TOPO plasmid. For confirmation of the inserted chimeric genes, colony PCR was performed using expressed colonies as a template. 8 kinds of chimeric $\beta$-glucosidase genes were introduced into the pCR-TOPO plasmid and these were confirmed with colony PCR. This confirmation was also shown positively in the other 7 chimeric genes (data not shown). From the colony PCR, some successfully inserted chimeric genes for 8 different chimeric $\beta$-glucosidase types were obtained. Colony PCR was found to be a fast and convenient method for confirmation of inserted target DNA fragments.

\section{Selection of active chimeric $\boldsymbol{\beta}$-glucosidase colonies}

For the selection of active chimeric $\beta$-glucosidase colonies, TOPO plasmids were transferred into the pET28a (+) vector, and colony PCR was performed to confirm the presence of the inserted chimeric gene. BL21 (DE3) cells were then transformed with the plasmid and spread on a solid plate containing pNP- $\beta$-D-glucopyranoside. We obtained some successfully inserted chimeric gene colonies for 8 designed chimeric types from colony PCR. However, only 2 kinds of active chimeric $\beta$-glucosidases were obtained from No.6 and No. 8 chimeric types. Activities of other types of chimeric $\beta$-glucosidases were not expressed. Inclusion bodies were produced due to the over-production by the pET28a $(+)$ vector $[19,20,21]$. In some instances, the chimeric proteins were unfolded in structure $[22,23]$.

\section{Purification of enzymes}

The pET vector is known to be a powerful expression system [24,25], and over-produced chimeric $\beta$-glucosidases can accumulate in an insoluble form. Harvested cells were suspended in $25 \mathrm{mM}$ MOPS buffer ( $\mathrm{pH}$ 6.5) and then disrupted by sonication. The soluble fraction was obtained by centrifugation of the sonically treated cell suspension at $15,000 \mathrm{rpm}$ for $15 \mathrm{~min}$. The resultant pellet was solublized in $8 \mathrm{M}$ urea solution in the above-mentioned buffer, and after centrifugation (15,000 rpm for $15 \mathrm{~min})$, the supernatant was used as the insoluble fraction $[15,26,27]$. The proteins in both the soluble and insoluble fractions of No.6 and No.8 were analyzed by 7.5\% SDS-PAGE followed by Coomassie Brilliant Blue staining and the molecular mass of both protein constructs were found to be around $80 \mathrm{kDa}$ (Fig. 2 ). The activities of the chimeric $\beta$-glucosidases were monitored at each step of the purification process and these activities are summarized in Table 2. Enzyme activities of both chimeric $\beta$-glucosidases were not very different from each other based on the specific activity that was calculated. 


\begin{tabular}{cccccccccc}
\hline \multirow{2}{*}{ Purification step } & $\begin{array}{c}\text { Protein } \\
\text { (mg) }\end{array}$ & \multicolumn{2}{c}{$\begin{array}{c}\text { Total activity } \\
\text { (unit) }\end{array}$} & $\begin{array}{c}\text { Specific activity } \\
\text { (unit/mg) }\end{array}$ & Purification factor(fold) $\begin{array}{c}\text { Recovery } \\
\text { (\%) }\end{array}$ \\
\cline { 2 - 10 } No.6 No.8 & No.6 & No.8 & No.6 & No.8 & No.6 & No.8 & No.6 No.8 \\
\hline Crude extract & 335 & 350 & 55.3 & 49.5 & 0.17 & 0.14 & 1.0 & 1.0 & 100100 \\
Ni-NTA & 16.7515 .05 & 24.8 & 18.8 & 1.48 & 1.25 & 8.71 & 8.93 & 44.838 .0 \\
Mono-S & 2.43 & 2.03 & 13.5 & 9.2 & 5.55 & 4.53 & 32.65 & 32.35 & 24.418 .6 \\
\hline
\end{tabular}

Table 2. Purification step for chimeric $\beta$-glucosidases.

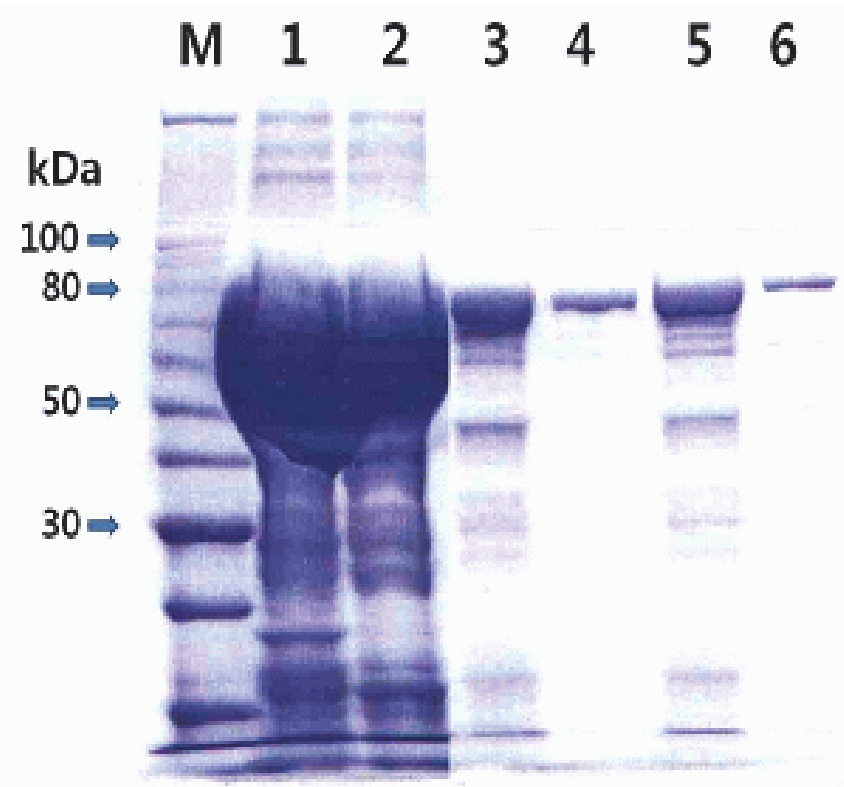

Fig. 2. SDS-PAGE of soluble and insoluble fractions of chimeric $\beta$-glucosidase from No.6 and No. 8.

Lane M, Marker; lane 1 and 2, insoluble fraction of pET-chimeric $\beta$-glucosidase after IPTG induction of No. 6 and No.8, respectively; lane 3 and 5, soluble fraction of pET-chimeric $\beta$ glucosidase after IPTG induction of No.6 and No.8, respectively; lane 4 and 6, purification on Mono-S column after Ni-NTA-agarose slurry.

\section{pH stability and optimum pH}

The influence of $\mathrm{pH}$ on the chimeric $\beta$-glucosidase activity was determined using a series of various buffers at $30^{\circ} \mathrm{C}$. The stability test [28] of the purified enzyme at different $\mathrm{pH}$ levels indicated that it was stable in the $\mathrm{pH}$ range of 3.0 to 5.0 for No.6 chimeric enzyme and 3.0 to 7.0 for No.8 chimeric enzyme at $30^{\circ} \mathrm{C}$. The $\mathrm{pH}$ stability for the parents of these chimeric enzymes was followed the pervious paper(5,15), CG and Tm were $\mathrm{pH} 4.0$ to 8.0 and $\mathrm{pH} 4.0$ to 12.0 , respectively (Fig. 3). For $\mathrm{pH}$ stability, chimeric enzymes generally correlate with the parental enzymes. The shuffling regions in the C-terminal domain may have played a very important role in enzyme-folding and stability because both chimeric genes were replaced 


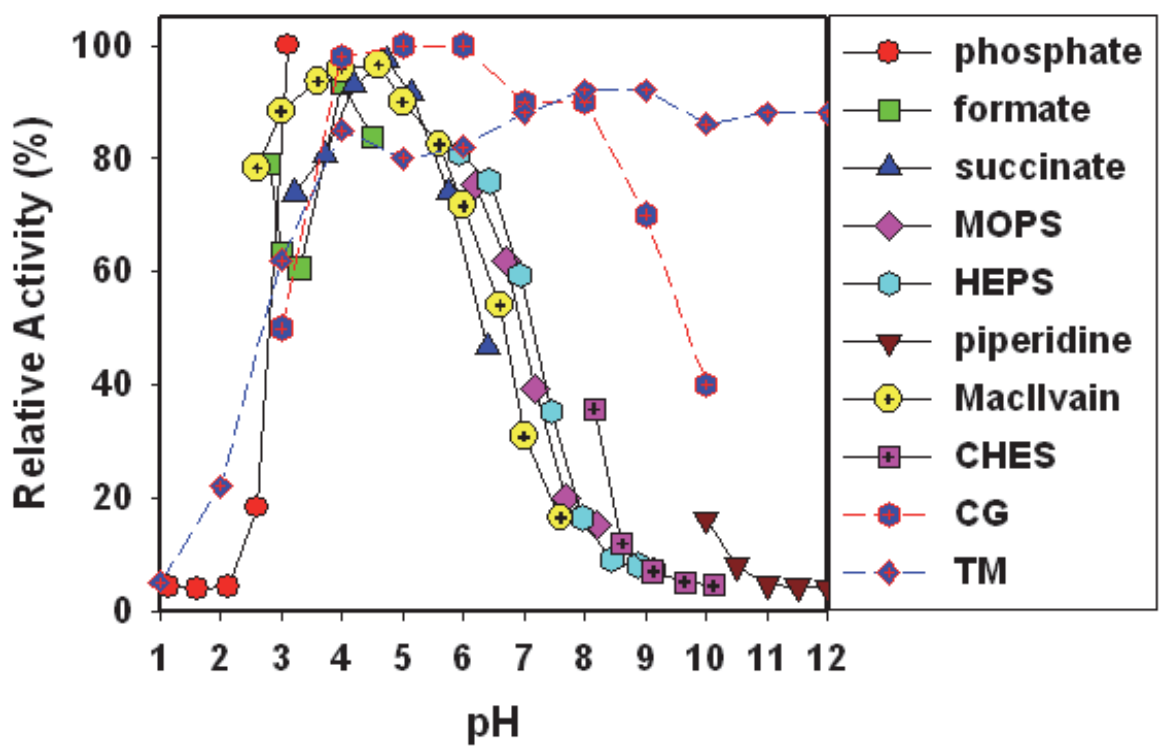

(a)

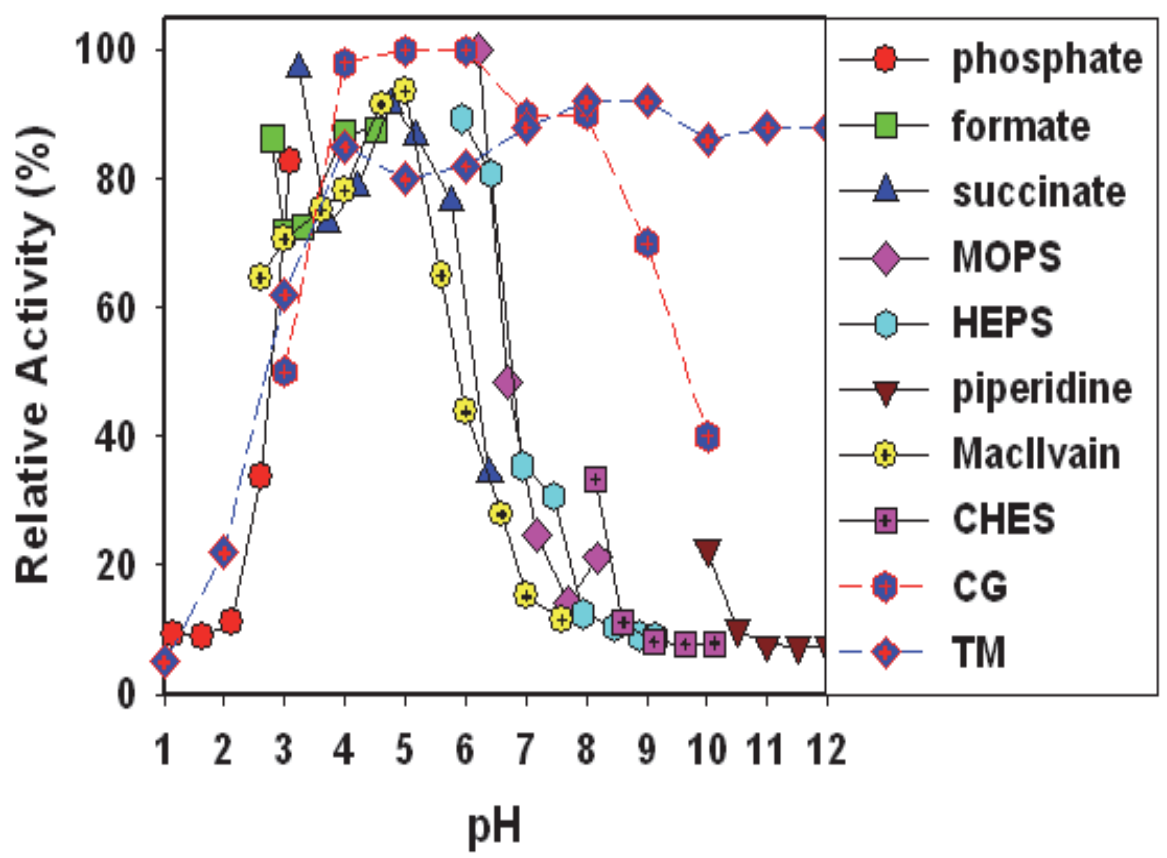

(b)

Fig. 3. pH stability range of No.6 (a) and No.8 (b) chimeric enzyme. CG and Tm as parents of these chimeric enzymes. 


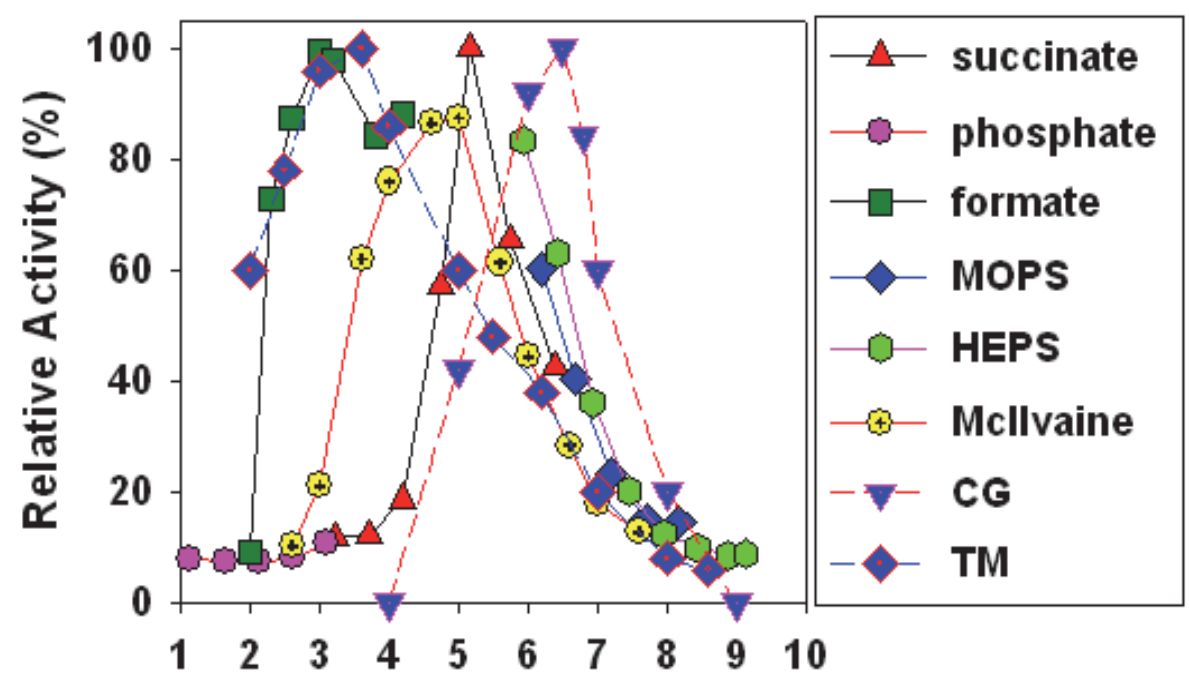

$\mathrm{pH}$

(a)

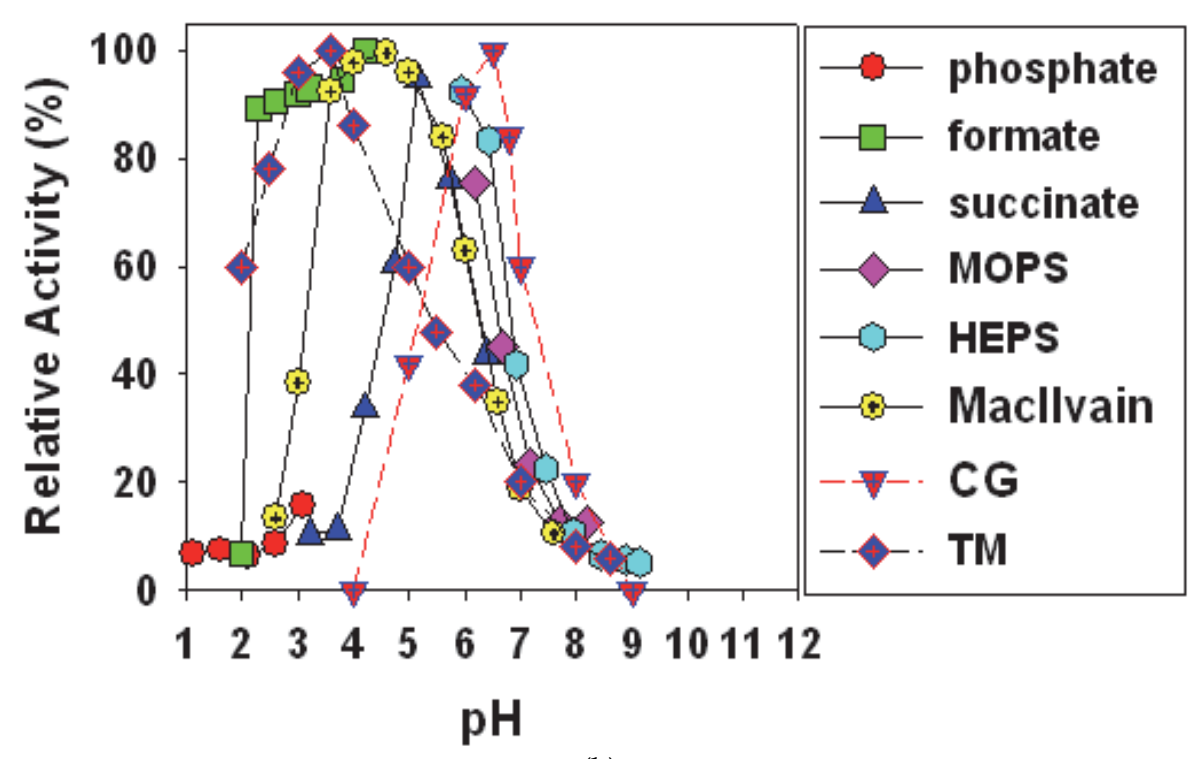

(b)

Fig. 4. Optimum pH of No.6 (a) and No.8 (b) chimeric enzyme. CG and Tm as parents of these chimeric enzymes.

with CG terminal domain by $20 \%$ (No.6-chimeric enzyme) and 12\% (No.8-chimeric enzyme) on the whole TM gene. For determining the optimum $\mathrm{pH}$ of the chimeric enzymes, the $\mathrm{pH}$ 
of the parent enzymes was investigated. The optimum $\mathrm{pH}$ of $\mathrm{CG}$ and $\mathrm{Tm}$ was reported to be 6.4 and 3.4, respectively (Fig. 4). The optimum pH of No.6 chimeric enzymes was found to be 3.0 and 5.0, which showed different maximum activity according to the buffer used. No.8 chimeric enzyme showed an optimum $\mathrm{pH}$ of 4.5. The optimum $\mathrm{pH}$ profile of both chimeric enzymes is closer to that of TM than that of CG. The optimum $\mathrm{pH}$ of No.6 and No.8 was shifted between both the optimum $\mathrm{pH}$ properties of CG and TM, which is an indication of inherited $\mathrm{pH}$ properties.

\section{Thermal stability and optimum temperature}

The enzyme activity correlated with the $\mathrm{pH}$ unit. The optimum $\mathrm{pH}$ was reported at two different positions that varied according to the buffer used. The optimum temperature therefore, also varied between the two different $\mathrm{pH}$ points, $\mathrm{pH} 3.0$ (formate buffer) and $\mathrm{pH}$ 5.0 (succinate buffer) for No.6 chimeric enzyme, and $\mathrm{pH} 4.5$ (McIlvain buffer) for No.8 chimeric enzyme (Fig. 5). The optimum temperature of CG and TM was found to be $30^{\circ} \mathrm{C}$ and $70^{\circ} \mathrm{C}$, respectively. The optimum temperature of the chimeric enzymes of No.6 (pH 5.0) and No.8 (pH 4.5) was reported to be at $60^{\circ} \mathrm{C}$, and No.6 (pH 3.0) at $50^{\circ} \mathrm{C}$, even though the activity was very low(Fig. 6). The optimum temperature of both chimeric $\beta$-glucosidases were found to lie between that of CG and TM. A temperature stability test was carried out for the parental and chimeric enzymes. For estimation of the heat stability of each $\beta$ glucosidase, residual activity was determined using a standard assay after a $30 \mathrm{~min}$ preincubation at various temperatures. The heat stability of $\mathrm{CG}$ and $\mathrm{TM}$ was at $41^{\circ} \mathrm{C}$ and $87^{\circ} \mathrm{C}$

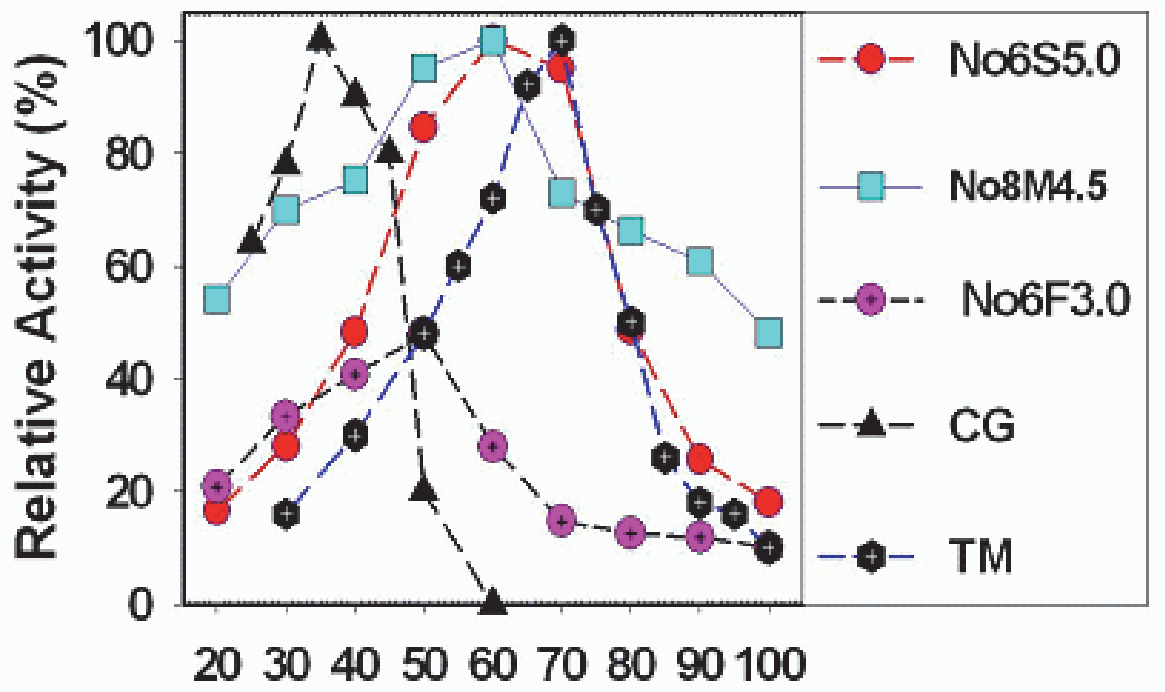

\section{Temperature $\left({ }^{\circ} \mathrm{C}\right)$}

Fig. 5. Optimum temperature of No. 6 and No. 8 chimeric $\beta$-glucosidase with the buffer used, CG and TM as parents $\beta$-glucosidase.

$S$ : Succinate buffer, M: McIlvain buffer, F: Formate buffer 
respectively, while those of the chimeric enzymes of No.6 and No.8 were $70^{\circ} \mathrm{C}$ and $74^{\circ} \mathrm{C}$ respectively. The heat stability of the chimeric enzymes increased by $29-33^{\circ} \mathrm{C}$ relative to $\mathrm{CG}$. himeric $\beta$-glucosidases were more stable than CG, but less stable than TM. These results demonstrated that the temperature stability of the chimeric enzymes generally correlated well with the thermal stability of the parental enzymes. In addition, the optimal temperature for the enzymatic reaction correlated successfully with the heat stability of the enzyme.

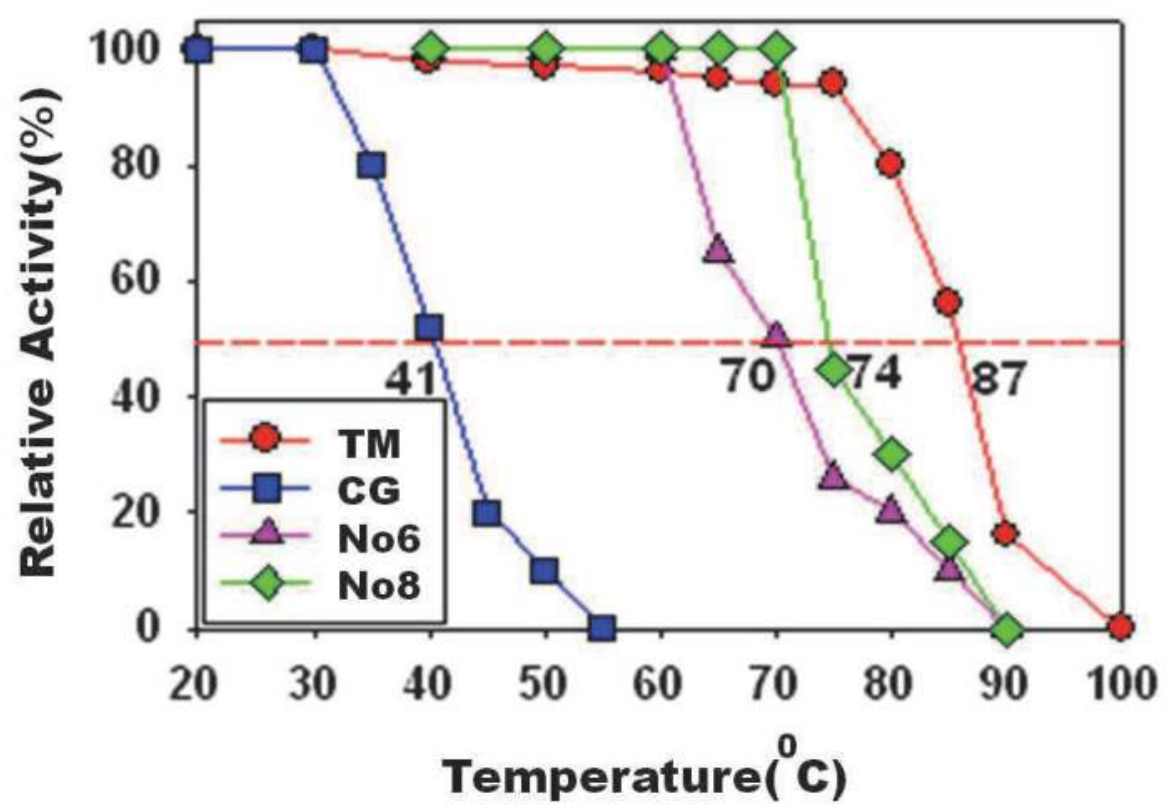

Fig. 6. Effect of temperature on the thermal stability of the chimeric $\beta$-glucosidase, CG and TM as parents of $\beta$-glucosidase. For estimation of the heat stability of the each $\beta$-glucosidase, residual activity was determined using a standard assay after a $30 \mathrm{~min}$ pre-incubation at various temperatures.

\section{Kinetic parameters}

The kinetic parameters of the two parental and chimeric $\beta$-glucosidases were investigated using pNP- $\beta$-D-glucopyranoside as the substrate(Table 3 ). The observed $\mathrm{Km}$ values for the chimeric No.6 and No.8 enzymes toward pNP- $\beta$-D-glucopyranoside were calculated to be 0.012 and $0.0082 \mathrm{mM}$, respectively. These $\mathrm{Km}$ values were lower than that of CG $(0.44 \mathrm{mM})$, but are more or less similar to that obtained for TM $(0.0039 \mathrm{mM})$. However, the Kcat values observed for the chimeric No.6 and No.8 enzymes were 5.62/sec and 3.38/sec respectively, which is lower than that obtained for both prental enzymes, i.e. TM $(6.4 / \mathrm{sec})$ and CG $(42.2 / \mathrm{sec})$. This indicated that the substrate specificities of the chimeric enzymes No.6 and No.8 were similar to each other and were closer to that of TM than CG. Also, No.8 chimeric $\beta$-glucosidase showed greater affinity toward pNP- $\beta$-D-glucopyranoside than that of No.6 chimeric enzyme. Thus the shuffling regions in the C-terminal domain produced a slight effect on the enzyme's substrate specificity and catalytic efficiency. 


\begin{tabular}{cccc}
\hline Enzymes & Km $(\mathrm{mM})$ & Kcat $(/ \mathrm{sec})$ & Kcat $/ \mathrm{Km}(\mathrm{mM} / \mathrm{sec})$ \\
\hline TM & 0.0039 & 6.4 & 1640 \\
No.6 & 0.012 & 5.62 & 468 \\
No.8 & 0.0082 & 3.84 & 468 \\
CG & 0.44 & 42.2 & 95.9 \\
\hline
\end{tabular}

Table 3. Kinetic parameters of the parental and chimeric $\beta$-glucosidases toward pNP- $\beta$-Dglucopyranoside

\section{Concluding remarks}

Chimeric $\beta$-glucosidases with improved enzymatic properties can be prepared in a convenient and effective way manipulating homology region of parental enzymes with overlapping PCR. The characteristics of the daughter enzymes suach as stability and optimization of $\mathrm{pH}$ and temperature, kinetic parameters were inherited with inter-mediate properties of parents. Also, the shuffling regions in the C-terminal domain may have played a very important role in determining enzyme characteristics, and changes in enzymatic properties.

\section{References}

[1] Béguin, P.(1990) Molecular biology of cellulose degradation. Annu. Rev. Microbiol. 44; 219-248.

[2] Paavilainen, S., J. Hellman, and T. Korpela(1993) Purification, characterization, gene cloning, and sequencing of a new beta-glucosidase from Bacillus circulans subsp. alkalophilus. Appl. Environ. Microbiol. 59;927-932.

[3] Shewale, J.G.(1982) Beta-Glucosidase: its role in cellulase synthesis and hydrolysis of cellulose. Int. J. Biochem.14; 435-443.

[4] Singh, A., K. and Hayashi(1995) Construction of chimeric $\beta$-glucosidases with improved enzymatic properties. JBC. 270; 21928-21935.

[5] Glick, B.R. and J. J. Pasternak(1989) Isolation, characterization and manipulation of cellulase genes. Biotechnol. Adv. 7; 361-386.

[6] Guo, R., M. Ding,S. L. Zhang, G. J. Xu , and F.K. Zhao(2008) Molecular cloning and characterization of two novel cellulase genes from the mollusc Ampullaria crossean. $J$. Comp. Physiol.178; 209-215.

[7] Roy, P., S. Mishra, and T. K. Chaudhuri(2005) Cloning, sequence analysis, and characterization of a novel beta-glucosidase-like activity from Pichia etchellsii. Biochem. Biophys. Res. Commun.336; 299-308.

[8] YKim , Y.M, S.H. Jung, Y.H. Chung, C. B. Yu, and I. K. Rhee(2008) Cloning and Characterization of a Cyclohexanone Monooxygenase Gene from Arthrobacter sp. L661. Biotechnol. Bioprocess Eng. 13; 40-47.

[9] Singh, A. and K. Hayashi(1995) Microbial celluoases, protein architecture, molecuar properties and biosynthesis. Adv. Appl. Microbiol.40;38-44.

[10] Tao, A. L. and S. H. He(2004) Bridging PCR and partially overlapping primers for novel allergen gene cloning and expression insert decoration. World J. Gastroenterol. 10; 2103-2108. 
[11] Crameri, A., S.A.Raillard, E. Bermudez, and W.P.Stemmer(1998) DNA shuffling of a family of genes from diverse species accelerates directed evolution. Nature. 391; 288-291.

[12] Lehmann, M., L. Pasamontes, S. F. Lassen, and M. Wyss(2000) The consensus concept for thermostability engineering of proteins. Biochim.Biophys. Acta. 1543; 408-15

[13] Singh, S.P., J. D. Kim, S. Machida, and K. Hayashi(2002) Overexpression and protein folding of a chimeric $\beta$-glucosidase constructed from Agrobacterium tumefaciens and Cellvibrio gilvus, Ind. J. Biochem. Biophys. 39; 235-239.

[14] Lisy, O., B.K. Huntley, D.J. McCormick, P.A. Kurlansky, and J.C. Burnett $\operatorname{Jr}(2008)$ Design, synthesis, and actions of a novel chimeric natriuretic peptide: CD-NP. J. Am. Coll. Cardiol.52; 60-68.

[15] Shibuya, H., S. Kaneko, and K. Hayashi(2000) Enhancement of the thermostability and hydrolytic activity of xylanase by random gene shuffling. Biochem. J. 349;651-656.

[16] Singh, A., K. Hayashi,T.T. HOA, Y. Kashiwagi, and K. Tokuyasu(1955) Construction and characterization of chimeric $\beta$-glucosidase. Biochem. J. 305; 715-719.

[17] Bhat, K.M.J.S. Gaikwad, and R. Maheshwari(1993) Purification and characterization of an extracellular $\beta$-glucosidase from thermophiic fungus S.thermophile and its influence on cellulae activity. J. Gen. Microbiol. 139; 2825-2832.

[18] D'Auria, S., R. Nucci, M. Rossi, E. Bertoli, F.Tanfani, I.Gryczynski, H. Malak, and J. R. Lakowicz (1999) $\beta$-glucosidase from the hyperthermophilic Archaeon Sulfoobus Solfataricus: structure and activity in presence of alcohols. J. Biochem. 126;545-52.

[19] Di Lorenzo, M.,A. Hidalgo, M. Haas, and U. T. Bornscheuer(2005) Heterologous production of functional forms of Rhizopus oryzae lipase in Escherichia coli. Appl. Environ. Microbiol. 71; 8974-8977.

[20] Gasparian, M.E.,V.G. Ostapchenko, A.V. Yagolovich, I.N. Tsygannik,B.V. Chernyak, D.A. Dolgikh, M.P. Kirpichnikov (2007) Overexpression and refolding of thioredoxin/ TRAIL fusion from inclusion bodies and further purification of TRAIL after cleavage by enteropeptidase. Biotechnol. Lett. 29; 1567-1573.

[21] Wakarchuk, W.W., N.M. Greenberg, D.G. Kilburn, R.C. Miller Jr, and R.A. Warren(1988) Structure and transcription analysis of the gene encoding a cellobiase from Agrobacterium sp. strain ATCC 21400. J. Bacteriol.170; 301-307.

[22] Iwahashi, J., S. Furuya, K. Mihara, and T. Omura(1992) Characterization of adrenodoxin precursor expressed in Escherichia coli. J. Biochem.111; 451-455.

[23] Parakhnevitch, N.M., A.A. Malygin, and G.G. Karpova(2005) Recombinant human ribosomal protein S16: expression, purification, refolding, and structural stability. Biochemistry(Mosc).70; 777-781.

[24] Pan, S.H. and B.A. Malcolm(2000) Reduced background expression and improved plasmid stability with pET vectors in BL21 (DE3). Biotechniques. 29;1234-1238.

[25] Stemmer, W.P.(1994) Rapid evolution of a protein in vitro by DNA shuffling. Nature. 370; 389-91.

[26] Machida, S., Y. YU, S.P. SINGH, J.D. Kim, K. Hayashi, and Y. Kawata(1998) Overproduction of $\beta$-glucosidase as active form by Eschericha coli system coexpressing the chaperonin GroELS at 25. FEMS. MICROBIOL. LETT. 159; 41-46. 
[27] Wang ,X., M. Fu, J. Ren, and X. Qu(2007) Evaluation of different culture conditions for high-level soluble expression of human cyclin A2 with pET vector in BL21 (DE3) and spectroscopic characterization of its inclusion body structure. Protein Expr. Purif. 56; 27-34.

[28] Lien , T. S., S. T. Yu, S. T. Wu, and J. R. Too(2007)Induction and Purification of a Thermophilic Chitinase Produced by Aeromonas sp. DYU-Too7 Using Glucosamine. Biotechnol. Bioprocess Eng. 12 ; 610-617. 


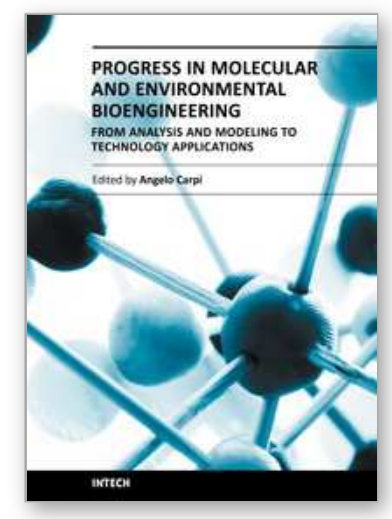

\author{
Progress in Molecular and Environmental Bioengineering - From \\ Analysis and Modeling to Technology Applications \\ Edited by Prof. Angelo Carpi
}

ISBN 978-953-307-268-5

Hard cover, 646 pages

Publisher InTech

Published online 01, August, 2011

Published in print edition August, 2011

This book provides an example of the successful and rapid expansion of bioengineering within the world of the science. It includes a core of studies on bioengineering technology applications so important that their progress is expected to improve both human health and ecosystem. These studies provide an important update on technology and achievements in molecular and cellular engineering as well as in the relatively new field of environmental bioengineering. The book will hopefully attract the interest of not only the bioengineers, researchers or professionals, but also of everyone who appreciates life and environmental sciences.

\title{
How to reference
}

In order to correctly reference this scholarly work, feel free to copy and paste the following:

Kim Jong Deog and Hayashi Kiyoshi (2011). Construction and Characterization of Novel Chimeric $\beta$ Glucosidases with Cellvibrio gilvus (CG) and Thermotoga maritima (TM) by Overlapping PCR, Progress in Molecular and Environmental Bioengineering - From Analysis and Modeling to Technology Applications, Prof. Angelo Carpi (Ed.), ISBN: 978-953-307-268-5, InTech, Available from:

http://www.intechopen.com/books/progress-in-molecular-and-environmental-bioengineering-from-analysisand-modeling-to-technology-applications/construction-and-characterization-of-novel-chimeric-glucosidaseswith-cellvibrio-gilvus-cg-and-therm

\section{INTECH}

open science | open minds

\author{
InTech Europe \\ University Campus STeP Ri \\ Slavka Krautzeka 83/A \\ 51000 Rijeka, Croatia \\ Phone: +385 (51) 770447 \\ Fax: +385 (51) 686166 \\ www.intechopen.com
}

\author{
InTech China \\ Unit 405, Office Block, Hotel Equatorial Shanghai \\ No.65, Yan An Road (West), Shanghai, 200040, China \\ 中国上海市延安西路65号上海国际贵都大饭店办公楼405单元 \\ Phone: +86-21-62489820 \\ Fax: +86-21-62489821
}


(C) 2011 The Author(s). Licensee IntechOpen. This chapter is distributed under the terms of the Creative Commons Attribution-NonCommercialShareAlike-3.0 License, which permits use, distribution and reproduction for non-commercial purposes, provided the original is properly cited and derivative works building on this content are distributed under the same license. 